\title{
Temporomandibular disorders in fibromyalgia: a critical view
}

\section{Disfunção temporomandibular na fibromialgia: uma visão crítica}

\author{
Luana Maria Martins de AQUINO \\ Department of Prosthesis and Periodontology - Piracicaba Dental School - UNICAMP - University of \\ Campinas - Piracicaba - SP - Brazil.
}

\section{Maisa Soares GUI}

Department of Morphology - Piracicaba Dental School - UNICAMP - University of Campinas Piracicaba - SP - Brazil.

\section{Marcele Jardim PIMENTEL}

Department of Prosthesis and Periodontology - Piracicaba Dental School - UNICAMP - University of Campinas - Piracicaba - SP - Brazil.

\section{Rubens REIMÃo \\ Department of Neurology - São Paulo University Medical School - São Paulo -SP - Brazil.}

\section{Célia Marisa RIZZATTI-BARBOSA}

Department of Prosthesis and Periodontology - Piracicaba Dental School - UNICAMP - University of Campinas - Piracicaba - SP - Brazil.

\begin{abstract}
Temporomandibular disorders (TMD) and fibromyalgia (FM) are musculoskeletal syndromes that appear to be associated to each other. Various studies throughout the literature relate the signs and symptoms of TMD in patients with FM. The objective of this study was to analyze the literature regarding clinical association between FM and TMD. Even though these conditions present different etiologies, the pain modulating mechanisms are similar. Many studies in this field aim to elucidate questions which are still little understood. However, it has been observed that these syndromes are characterized by a reduction in pain threshold and in the attenuation capabilities of descending pain modulating systems. Moreover, there is a certain degree of comorbidities between these two pathologies, which share many clinical characteristics. Numerous patients with FM present various signs and symptoms of TMD, while only a small quantity of individuals with TMD is diagnosed with FM. Therefore, an adequate and precise evaluation of the stomatognathic system in patients with FM, which encompasses TMD diagnosis in therapeutic intervention, is paramount.
\end{abstract}

\section{KEYWORDS}

Temporomandibular disorder; fibromyalgia; facial pain.

\section{INTRODUCTION}

Temporomandibular disorder (TMD) is a syndrome which primarily involves structures of the stomatognathic system, such as masticatory muscles, temporomandibular joints, cervical muscles, as well as other related elements, like blood vessels and nervous structures [1]. The disorder is of great relevance, since nearly $10 \%$ of the adult population presents some sign or symptom of TMD [2]. Among the most common signs and symptoms, one can observe limitation of mandibular motions, difficulty in mastication and mouth opening, TMJ sounds, and, almost always, intense craniocervical pain. Its etiology seems to involve more than just teeth occlusion, and it is now believed that its diagnosis should contemplate predisposition elements, as well as the triggering and perpetuating factors, among 
which genetic predisposition [3-5] and psycho-socioeconomical conditions [6-9] are included.

Facial pain is one of the most influential reasons for seeking a healthcare provider, since it can lead to important physical, psychological, and social limitations to the patient, regardless of whether the pain is localized or referred [10-11]. However, the diagnosis of facial pain is not simple and involves various confounding factors, such as the situations and syndromes which are characterized by the presence of pain in the maxillomandibular region and annexed structures. Among these conditions are included sinusitis, tension headaches, cranial nerves neuralgia, atypical facial pains, Eagle's syndrome, stylohyoid ligament syndrome, facial reflex sympathetic dystrophy, cervical radiculopathy, neck tension, cervicothoracic interspinous bursitis, supraspinatus syndrome, intercostals neuralgias, thoracic vertebral compression, spinal stenosis, benign and malignant lesions of the maxillomandibular complex, as well as fibromyalgia (FM) [12].

Fibromyalgia is a syndrome of still unknown etiology, characterized by chronic and diffuse pain, muscle rigidness, non-repairing sleep, fatigue, and comorbidity conditions [13]. According to the American College of Rheumatology, patients with fibromyalgia present generalized pain through the body for at least 3 months, as well as positive palpation of at least 11 of the 18 specific tender points [14]. This syndrome is among the most common musculoskeletal rheumatoid diseases affecting the adult population, and epidemiological studies point to a predominance in females. Table 1 illustrates a chronological perspective regarding major studies about the prevalence of FM in the human population.

\section{Table 1 - Chronological and topographical Perspective of the MAJor Studies Regarding THE PREVALENCE OF FIBROMYALGIA IN THE HUMAN POPULATION}

\begin{tabular}{|c|c|c|c|c|c|}
\hline AUTHOR & YEAR & LOCATION & $\mathrm{N}$ & METHOD & RESULTS \\
\hline $\begin{array}{c}\text { Makela \& } \\
\text { Heliovaara [15] }\end{array}$ & 1991 & Finland & 3434 & Interview and tender points localization by palpation & $1,57 \%$ \\
\hline $\begin{array}{c}\text { Prescott et al. } \\
{[16]}\end{array}$ & 1993 & Denmark & 123 & $\begin{array}{l}\text { American College of Rheumatology criteria for } \\
\text { fibromyalgia }\end{array}$ & $0.66 \%$ \\
\hline $\begin{array}{l}\text { Forseth \& } \\
\text { Gran [17] }\end{array}$ & 1993 & Norway & 2498 women & $\begin{array}{l}\text { Questionnaire regarding the presence of pain, as } \\
\text { well as exams according to rheumatic disease } \\
\text { criteria }\end{array}$ & $10,5 \%$ \\
\hline $\begin{array}{l}\text { Wolfe et al. } \\
\quad[18]\end{array}$ & 1995 & $\begin{array}{l}\text { London - } \\
\text { England }\end{array}$ & 391 & $\begin{array}{l}\text { Questionnaire regarding the presence of no pain, } \\
\text { non-diffuse pain, and diffuse pain }\end{array}$ & $\begin{array}{l}3.4 \% \text { for women; } \\
\text { and } 0.5 \% \text { for men. } \\
\text { Prevalence increases } \\
\text { with age }\end{array}$ \\
\hline $\begin{array}{l}\text { White et al. } \\
\quad[19]\end{array}$ & 1999 & $\begin{array}{l}\text { Kansas - } \\
\text { EUA }\end{array}$ & 311 & $\begin{array}{l}\text { American College of Rheumatology criteria for } \\
\text { fibromyalgia }\end{array}$ & $\begin{array}{l}3.4 \% \text { for women and } \\
0.5 \% \text { for men }\end{array}$ \\
\hline $\begin{array}{l}\text { Lindell et al. } \\
\quad[20]\end{array}$ & 2000 & Sweden & 147 & $\begin{array}{l}\text { Use of algometer for assessing tender points, } \\
\text { pain threshold, prevalence of chronic pain and } \\
\text { fibromyalgia }\end{array}$ & $1,3 \%$ \\
\hline $\begin{array}{l}\text { Lundberg \& } \\
\text { Gerdle [21] }\end{array}$ & 2002 & $\begin{array}{l}\text { Nikoping - } \\
\text { Sweden }\end{array}$ & 643 women & $\begin{array}{l}\text { Presence of tender points, quality of life, pain } \\
\text { provocation index, presence and intensity of pain, } \\
\text { quality of vacation, and time away from work due } \\
\text { to pain }\end{array}$ & $2.0 \%$ \\
\hline $\begin{array}{l}\text { Schochat \& } \\
\text { Rasp [22] }\end{array}$ & 2003 & Germany & 623 women & $\begin{array}{l}\text { Subjects were clinically evaluated regarding the } \\
\text { presence of trigger points }\end{array}$ & $11,5 \%$ \\
\hline $\begin{array}{l}\text { Salaffi et al. } \\
\text { [23] }\end{array}$ & 2005 & Italy & 2155 & $\begin{array}{l}\text { Questionnaire were sent by mail to subjects, which } \\
\text { were then evaluated by trained rheumatologists }\end{array}$ & $2,2 \%$ \\
\hline $\begin{array}{l}\text { Topbas et al. } \\
\text { [24] }\end{array}$ & 2005 & Turkey & 1930 women & $\begin{array}{l}\text { Interview regarding items related to the diagnosis of } \\
\text { fibromyalgia and examination by a speciallist }\end{array}$ & $3.6 \%$ \\
\hline Haq et al. [25] & 2005 & Bangladesh & 5211 & $\begin{array}{l}\text { Questionnaire conducted door-to-door by } \\
\text { trained interviewers, and examination by trained } \\
\text { rheumatologists to those who responded positively } \\
\text { to the presence of musculoskeletal pain }\end{array}$ & $4,4 \%$ \\
\hline Mas [26] & 2008 & Spain & 2192 & $\begin{array}{l}\text { Classification and exams conducted by } \\
\text { experience rheumatologists, which investigated } \\
\text { musculoskeletal dysfunctions by validated } \\
\text { instruments found in the literature }\end{array}$ & $\begin{array}{l}2.4 \% \text {; of which } 4.2 \% \text { in } \\
\text { women and } 0,2 \% \text { in men }\end{array}$ \\
\hline
\end{tabular}




\begin{tabular}{|c|c|c|c|c|c|}
\hline $\begin{array}{l}\text { Assumpção et } \\
\text { al. [27] }\end{array}$ & 2009 & $\begin{array}{l}\text { Embú - } \\
\text { Brasil }\end{array}$ & 304 & $\begin{array}{l}\text { Visual analog scale, questionnaire about the impact } \\
\text { of fibromyalgia, algometer over the tender points }\end{array}$ & $4,4 \%$ \\
\hline $\begin{array}{l}\text { Bannwarth et } \\
\text { al. [28] }\end{array}$ & 2009 & France & 1014 & $\begin{array}{l}\text { Questionnaire over the phone about the } \\
\text { epidemiological classification for fibromyalgia, } \\
\text { confirmatory exames conducted by trained } \\
\text { rheumatologists }\end{array}$ & $2,2, \%$ \\
\hline $\begin{array}{l}\text { Branco et al. } \\
\text { [29] }\end{array}$ & 2010 & $\begin{array}{l}\text { France, } \\
\text { Germany, } \\
\text { Italy, } \\
\text { Portugal } \\
\text { and Spain }\end{array}$ & 1225 & $\begin{array}{l}\text { Epidemiological classification questionnaire } \\
\text { for fibromyalgia of London, conducted over the } \\
\text { phone. Confirmatory exams conducted by } 8 \\
\text { rheumatologists according to the American College } \\
\text { of Rheumatology }\end{array}$ & 2,9 to $4,7 \%$ \\
\hline $\begin{array}{l}\text { Alvarez- } \\
\text { Nemegyei et } \\
\text { al. [30] }\end{array}$ & 2011 & Mexico & 3915 & $\begin{array}{l}\text { Transverse crossover study utilizing the Community } \\
\text { Orientated Program in the Rheumatic Diseases }\end{array}$ & $0,2 \%$ \\
\hline $\begin{array}{l}\text { Chaaya et al. } \\
\text { [31] }\end{array}$ & 2012 & Lebanon & $\begin{array}{c}3530 \\
\text { subjects } \\
\text { over } 15 \\
\text { years of } \\
\text { age, } 944 \\
\text { clinically } \\
\text { examined }\end{array}$ & $\begin{array}{l}\text { Interview by the Community Orientated Program in } \\
\text { the Rheumatic Diseases method, clinical evaluation } \\
\text { of positive cases with the American College of } \\
\text { Rheumatology criteria }\end{array}$ & $6,2 \%$ \\
\hline
\end{tabular}

Both TMD and FM can be considered functional disorders of the musculoskeletal system, which are not necessarily related to traumatic causes. According the World Health Organization [32], these disorders are among the greatest causes of morbidities in the world population, contributing to important socioeconomical issues and causing enormous burdens on healthcare systems. Approximately one quarter of Europe's adult population present musculoskeletal alteration capable of limiting their daily activities [33], and this reality could be very similar to that of Brazil. Even though it can appear in all age levels, musculoskeletal disorders tend to become aggravated as age progresses. Considering the increase of the elderly population in the world, and observing changes in life style that contribute to an increase in musculoskeletal alterations, there is a tendency that these diseases will overload healthcare systems in the near future.

\section{Pain Pathogenesis}

It is known that the pain found in FM is strongly related to an increase in central sensitization as a source of persistent musculoskeletal pain, which apparently is responsible for aggravation of chronic cranial pain $[34,35]$, and possibly the maxillofacial complex. Central sensitization is a phenomenon found in practically all chronic nociceptive or neuropathic pain events, where nociceptive stimuli induce a reduction in pain threshold, therefore creating hyperalgesia in primary sensitive areas and allodynia in areas adjacent to inflammation [35]. It is possible to believe that these reactions are closely correlated to spatial and temporal summation phenomena resulting from neuronal excitability [36, 37], which could account for greater prevalence of such cases in women rather than men [38]. Apparently, other regional painful syndromes are correlated, such as irritable bowel syndrome, interstitial cystitis, headaches, chronic low back pain, chronic neck pain, and some chronic manifestations of TMD, which appear to be associated with this abnormal amplification of nociceptive stimuli arising from visceral or musculoskeletal structures $[39,40]$. Although these syndromes posses different etiologies, the pain modulating mechanism appears to be the same. Moreover, these disturbances generally occur simultaneously [41], can act as risk factors for the development of another syndrome [42], or can lead to a transition from a localized pain disorder to a generalized pain condition [43]. While the beginning of these disorders result from peripheral pain mechanisms (inflammation and/ or irritation of mucosa or neural structures), the persistent nociceptive afferents lead to changes in the central nociceptive system. After induction of central sensitization, painful sensations can occur independently of peripheral nociceptive input [44], which significantly increases the complexity of treatment for such disorders. By broadening our comprehension of the shared pathophysiology of these conditions, it promotes greater collaboration between researches from different fields, in order to improve our ideas regarding the underlying mechanisms and aide in advancing treatment options for these pain processing disturbances.

In reality, the cause of increased sensitivity to pain in FM is still unknown, but the correlations of FM 
with sensitive processing alterations of the central nervous system have been identified, as well as the alterations in peripheral tissue [45]. The central abnormalities appear to be related to the blunting of the hypothalamic-hypophyseal axis with regards to response to stressor events [46,47], and to the increase in substance P levels $[48,49]$, excitatory amino acids [50], and neurotrophins in cerebrospinal fluid [51], as well as in activation and differentiation of glial cells in light of an exaggerated excitatory stimulus [45]. Pre-existing pain, psychological factors, congenital elements, sexual hormones, stress, negative emotions, depression and alterations in sleep patterns should be considered due to their importance in stabilizing spatial summation of the nociceptive afferents.

While our understanding of the developmental stages of chronic pain and hyperalgesia is traditionally focused on transmission of pain signals through ascending pathways (from periphery to the spinal and supra-spinal centers), a rising body of research amplifies our notion of the decreasing influence on generation and maintenance of sensitization [52]. The periaqueductal gray-rostral ventromedial medulla (PAG-RVM) is essential for descending modulation of pain. The influence of the descending inhibitory system (anti-nociceptive) has been documented for a long time [53]. The first evidence of its existence observed that the stimulation of PAG produced profound analgesia in rats [54]. The study demonstrated that the stimulation of PAG-RVM related to descending serotonergic, noradrenergic, and opioid pathways results in an analgesic response at the dorsal horn level.

\section{Correlation between TMD and FM}

The presence of signs and symptoms of TMD in individuals with FM was observed in 1988, when Ericksson et al. [55] conducted a study in Switzerland and observed a positive response to the presence of TMD signs in four of eight patients with primary FM. These patients were analyzed according to the Helkimo TMD index, but the same authors also suggested that a more detailed assessment of the stomatognathic system might have been necessary in order to elucidate possible etiological factors contributing to the subjects' complaints. Although this study can be taken into consideration due to its historic value, it also presents a series of experimental flaws, such as an extremely reduced sample size, an absence of a control group, a lack of proper examination, and other important methodological factors.
Hedenberg-Magnusson et al. (1997) [56], in another study from Switzerland, compared patients with FM, patients with TMD, and a control group, and observed that pain threshold due to pressure and pain tolerance levels were less for patients with FM than those with TMD. However, both groups were more sensitive to the painful stimuli than the individuals from control group. These authors concluded that patients with FM frequently have symptoms of TMD, primarily in relation to local myalgias.

The association between TMD and FM was defended by Fricton [57] in 2004, in which the author discussed the implications of comorbidities between diagnosis and treatment of TMD and FM. This research suggests that a straight correlation exists between both diseases. However, the author does not refer to important criteria pertinent to this conclusion, since there is no adequate information related to the populations studied, if correlations were found between the affected groups and the control groups, the classification methods utilized, and similar important aspects.

Manfredini et al. (2004) [58], investigated patients with TMD with regards to the presence of FM and viceversa, and observed that the difference between both groups was not relevant, with the exception of values for active and passive mouth opening, and for the presence of trigger points, which were more common and aggravated in individuals with FM. However, the majority of patients with FM (86.7\%) presented signs and symptoms within the stomatognathic system. On the other hand, only a fraction of the patients with TMD (10\%) presented signs and symptoms of FM when assessed by rheumatologic examination and evaluation. Plesh et al. (1996) [59] also studied the prevalence of TMD in patients with FM and viceversa, and discussed about which characteristics better distinguish between the two disorders. These authors verified that a small portion of patients with TMD (18.4\%) presented symptoms of FM, but most subjects with FM $(75.0 \%)$ complied with the criteria for myofascial TMD. Again, it was observed that patients with FM present inferior pain threshold than those with TMD.

Leblebici et al. (2007) [60] sought to determine the coexistence between FM, TMD, and myofascial masticatory pain (MMP). All patients were examined by a dentist and a physiatrist in order to assess the coexistence of FM and TMD. In the FM group, TMD was evidenced in $80 \%$ of the patients, and only $19 \%$ of them were of arthrogenic origin with MMP. In the TMD group, FM was observed in $52 \%$ of the patients, 
which was significantly higher in patients with TMD of arthrogenic origin with MMP. The results indicate that the coexistence of TMD and FM with MMP is high. Pain and the sensitivity of masticatory muscles seem to be an important element in FM, which may actually be the chief complaint in some patients.

Fraga et al. (2012) [61] observed the presence of signs and symptoms of TMD in patients with fibromyalgia. Sixty patients diagnosed with FM were evaluated by means of the Research Diagnostic Criteria for Temporomandibular Disorder (RDC-TMD), which provides standardized criteria for the diagnosis of TMD. The most common symptoms related by patients with FM were headaches (97\%) and facial pain $(81.7 \%)$. Myofascial pain without limitation of mouth opening was diagnosed in $47 \%$ of patients, which represents a subgroup I diagnosis on the RDCTMD. Dislocation of the disc with reduction was the most prevalent diagnosis in subgroup II (21.6\%), and $36.7 \%$ of subjects presented osteoarthritis, a subgroup III diagnosis. Only $6.6 \%$ of patients did not present any sign of TMD. There is an elevated prevalence of signs and symptoms of TMD in patients with FM, indicating the need of an integrated diagnosis and treatment approach to these patients, as it is suggested that FM can be a risk factor in the mid- to long-term for the development of TMD.

In light of the exposed, it is possible to notice that there is less evidence of suffering in patients with TMD, and that this condition is much more localized. However, FM is a generalized disorder, where many patients present symptoms of TMD, and these are generally muscular in nature, as opposed to articular. Possibly, muscular TMD, when induced by localized trauma [62,63] and associated to chronic stress [64], could alter the temporomandibular joints and cause sensitive modifications to joint biomechanics, which promotes capsular and discal microtraumas, and leads to a greater perception of pain. This would not necessarily be present in patients with FM, where pain from a centralized origin would be exerting greater influence in sensitivity to pain.

\section{Discussion}

There is still controversy when dealing with the pathophysiology of pain in FM and TMD. Various study strands are found in the literature, however there is still little consensus regarding this topic. It is understood that the comprehension of the pathophysiology of neurogenic pain, as well as its influence on pain perception threshold, is limited due to the infeasibility of experimental models in humans, since our behavior in response to pain is not the same as that observed in animals. The scarcity of studies with human subjects, due to ethical questions, urges the improvement of experimental models in animals to standards which are closely related to clinical reality. It is our belief that these translational studies, which establish correlation between experiments with animal models and the clinical, controlled, and randomized trials, are invaluable to comprehend and establish interventions for pain's triggering and maintenance mechanisms, specifically regarding FM and TMD.

In the same manner, some evidence suggests that congenital factors predispose some people to symptoms of chronic pain, both in FM $[65,66]$ and TMD [67-70]. Studies conducted by fellow researches [3-5] also confirm our hypothesis that polymorphic alterations appear to change the expression of signs and symptoms of TMD. Genetic mutations of a certain species are the foundation for its evolution, since it creates new elements (allele) which may or may not become part of the genetic pool for that population. When a genetic variance reaches a populational frequency of $1 \%$, it becomes a polymorphism. To date, many genetic polymorphisms are being related to an increase in occurrence and/or reoccurrence risk of various multifactorial pathologies, and are considered as part of the genetic component which increases the susceptibility of an individual to present certain behavior due to a certain factor, which consists as an augmented risk to this behavior. This is what occurs in pain expression in virtue to greater susceptibility to central neuronal alterations. It is our belief that this fact, as evidenced in the literature, will lead a new frontier of research which will elucidate the reason such alteration in pain modulating systems occur in certain groups of people. This will certainly open a new door of understanding to this intricate topic.

In light of this literature review, we conclude that a comorbidity between FM and TMD probably exist, since there is a high prevalence of TMD in patients with FM. This indicates a need for adequate diagnosis and management of signs and symptoms, suggesting that FM can be a mid- to long-term risk factors for the development of TMD [61]. Individuals with FM presented greater complexity with regards to their clinical TMD condition, therefore the importance of a precise and adequate evaluation of the stomatognathic systems in patients with FM is evident, and require greater care during diagnosis and therapeutic intervention. It is the responsibility of the 
dental surgeon to comprehend the complex nature of these diseases and, based on their particularities, propose not only care related to the ongoing pain, but especially identify the initial signs and symptoms related to FM and refer the patient to a rheumatologist. We suggest that, due to the complexities of the stomatognathic system and its interrelations with structures commonly involved in FM, the dental surgeon should be consulted in order to manage the orofacial manifestations of the disease, both in TMD and in the interventions aimed at the oral symptoms generated by FM.

\section{Resumo}

A disfunção temporomandibular (DTM) e a fibromialgia (FM) são síndromes musculo-esqueléticas que parecerem estar associadas. Vários estudos na literatura relatam sinais e sintomas da DTM em pacientes com FM. O objetivo deste trabalho foi analisar a literatura quanto à associação clínica entre fibromialgia e as disfunções temporomandibulares. Apesar de estes distúrbios possuírem etiologias diferentes, o mecanismo de modulação de dor é semelhante. Muitas pesquisas desenvolvidas nessa área buscam elucidar esta questão ainda pouco compreendida. Mas sugere-se que estas síndromes são caracterizadas por uma diminuição no limiar de dor e na capacidade de atenuação de sistemas descendente de modulação da dor. Além disso, há certo grau de comorbidade entre estas duas patologias, que compartilham muitas características clínicas. Muitos pacientes com FM apresentam vários sinais e sintomas de DTM, entretanto, uma pequena quantidade de indivíduos com DTM recebem um diagnóstico de FM. Portanto, é importante uma avaliação precisa e adequada do sistema estomatognático em pacientes com fibromialgia englobando o diagnóstico de disfunção temporomandibular na intervenção terapêutica.

\section{Palavras-chave}

Disfunção temporomandibular; fibromialgia; dor facial.

\section{REFERENCES}

1. Svensson P, Graven-Nielsen T. Craniofacial muscle pain: review of mechanisms and clinical manifestation. J Orofac Pain. 2001;15(2):117-45.

2. LeResche L. Epidemiology of temporomandibular disorders: implications for the investigation of etiologic factors. Crit Rev Oral Biol Med. 1997;8(3):291-305.

3. Ribeiro-Dasilva MC, Peres Line SR, Leme Godoy dos Santos MC, Arthuri MT, Hou W, Fillingim RB, et al. Estrogen receptor-alpha polymorphisms and predisposition to TMJ disorder. J Pain. 2009;10(5):527-33.

4. Meloto CB, Serrano PO, Ribeiro-DaSilva MC, RizzattiBarbosa CM. Genomics and the new perspectives for temporomandibular disorders. Arch Oral Biol. 2011;56(11):1181-91.

5. Planello AC, Campos MI, Meloto CB, Secolin R, Rizzatti-Barbosa CM, Line SR, L L. Association of matrix metalloproteinase gene polymorphism with temporomandibular joint degeneration. Eur J Oral Sci. 2011;119(1):1-6.

6. Gil IA, Rizzatti-Barbosa CM, Pedro VM, Silverio KC, Goldfarb DP, Fusco V et al. Multidisciplinary approach to chronic pain from myofascial pain dysfunction syndrome: a four-year experience at a Brazilian center. Cranio. 1998;16(1):17-25.

7. Johansson A, Unell L, Carlsson G, Söderfeldt B, Halling A, Widar F. Associations between social and general health factors and symptoms related to temporomandibular disorders and bruxism in a population of 50-year-old subjects. Acta Odontol Scand. 2004; 62(4):231-7

8. Burris JL, Evans DR, Carlson CR. Psychological correlates of medical comorbidities in patients with temporomandibular disorders. J Am Dent Assoc. 2010; 141(1):22-31.

9. Moufti MA, Wassell RW, Meechan JG, Allen PF, John MT, Steele JG. The Oral Health Impact Profile: ranking of items for temporomandibular disorders. Eur J Oral Sci. 2011;119(2):169-74.

10. Rizzatti-Barbosa CM, Nogueira MT, de Andrade ED, Ambrosano GM, Albergaria-Barbosa JR. Clinical evaluation of amitriptyline for the control of chronic pain caused by temporomandibular joint disorders. Cranio. 2003;21(3):221-5.

11. Rizzatti-Barbosa CM, Martinelli DA, Ambrosano GM, de Albergaria-Barbosa JR. Therapeutic response of benzodiazepine, orphenadrine citrate and occlusal splint association in TMD pain. Cranio. 2003;21(2):116-20.

12. Waldman SD. Atlas of common pain syndromes. 2 ed. Sauders: Elsevier; 2008.

13. Aaron LA, Burke MM, Buchwald D. Overlapping conditions among patients with chronic fatigue syndrome, fibromyalgia, and temporomandibular disorder. Arch Intern Med. 2000; 160(2):221-7.

14. Wolfe F, Smythe HA, Yunus MB, Bennett RM, Bombardier C, Goldenberg DL, et al. The American College of Rheumatology 1990 criteria for the classification fibromyalgia. Report of the multicenter criteria committee. Arthritis Rheum. 1990;33(2):160-72.

15. Makela M, Heliovaara M. Prevalence of primary fibromyalgia in the Finnish population. BMJ. 1991;303:216-19.

16. Prescott E, Kjøller M, Jacobsen S, Bülow PM, DanneskioldSamsøe B, Kamper-Jørgensen F. Fribromyalgia in the adult Danish population: I. A prevalence study. Scand J Rheumatol. 1993; 22(5): 233-5.

17. Forseth KO, Gran JT. The occurrence of fibromyalgia-like syndromes in a general female population. Clin Rheumatol. 1993;12(1):23-7. 
18. Wolfe TA, Ross K, Anderson J, Russell J. Aspects of fibromyalgia in the general population: Sex, pain threshold, and fibromyalgia symptoms. J Rheumatol. 1995; 22(1):151-6.

19. White KP, Speechley M, Harth M, Ostbye T. The london fibromyalgia epidemiology study: The prevalence of fibromyalgia Syndrome in London, Ontario. J Rheumatol. 1999; 26(7):1570-6.

20. Lindell L, Bergman S, Petersson IF, Jacobsson LT, Herrström P. Prevalence of fibromyalgia and chronic widespread pain. Scand J Prim Health Care. 2000;18(3):149-53.

21. Lundberg G, Gerdle B. Tender point scores and their relations to signs of mobility, symptoms, and disability in female home care personnel and the prevalence of fibromyalgia syndrome. J Rheumatol. 2002;29(3):603-13.

22. Schochat T, Rasp H. Elements of fibromyalgia in an open population. Rheumatology. 2003;42(7):829-35.

23. Salaffi FR, Angelis R De, Grassi W. Prevalence of musculoskeletal conditions in an Italian population sample: results of a regional community-based study. I. The MAPPING study. Clin Exo Rheumatol. 2005;23(6):819-28.

24. Topbas M, Cakirbay H, Gulec H, Akgol E, Ak I, Can G. The prevalence of fibromyalgia in women aged 20-64 in Turkey. Scand J Rheumatol. 2005;34(2):140-4.

25. Haq SA, Darmawan J, Islam MN, Uddin MZ, Das BB, Rahman $F$, et al. Prevalence of rheumatic diseases and associated outcomes in rural and urban communities in Bangladesh: a COPCORD study. J Rheumatol. 2005;32(2):348-53.

26. Mas AJ, Carmona L, Valverde M, Ribas B. EPISER Study Group. Prevalence and impact of fibromyalgia on function and quality of life in individuals from the general population: results from a nationwide study in Spain. Clin Exp Rheumatol. 2008; 26(4):519-26.

27. Assumpção A, Cavalcante AB, Capela CE, Sauer JF, Chalot $\mathrm{SD}$, Pereira CA et al. Prevalence of fibromyalgia in a low socioeconomic status population. BMC Musculoskeletal Disord. 2009;8:10-64.

28. Bannwarth B, Blotman F, Roué-Le Lay K, Caubère Jp, André E, Taïeb C. Fibromyalgia syndrome in the general population of France: a prevalence study. Joint Bone Spine. 2009;76(2):184-7.

29. Branco JC, Bannwarth B, Failde I, Abello Carbonell J, Blotman F, Spaeth M, et al. Prevalence of fibromyalgia: a survey in five European countries. Semin Arthritis Rheum. 2010;39(6):448-3.

30. Alvarez-Nemegyei J, Peláez-Ballestas I, Sanin LH, Cardiel MH, Ramirez-Angulo A, Goycochea-Robles MV. Prevalence of musculoskeletal pain and rheumatic diseases in the southeastern region of Mexico. A COPCORD-bases community survey. J Rheumatol. Suppl. 2011;86:21-5

31. Chaaya M, Slim ZN, Habib RR, Arayssi T, Dana R, Hamdan $\mathrm{O}$, et al. High burden of rheumatic diseases in Lebanon: a COPCORD study. Int J Rheum Dis. 2012;15(2):136-43.

32. World Health Organization (WHO). The burden of musculoskeletal conditions at the start of the new millennium: report of a WHO Scientific Group (internet). Geneva. WHO. 2003.; (cited 2010 Sep 15). Available from: http:whqlibdoc. who.int/trs/WHO_TRS_919.pdf.

33. Lidgren L, Smolen J, Bentley G, Delams P. European action towards better musculosckeletal health: a public health strategy to reduce the burden of musculoskeletal conditions (internet) Sweden. 2005.; (cited 2010 Mar 22) Available from: http://www. boneandjointdecade.org/Default.aspx? contId $=534$.

34. Wolfe F, Clauw DJ, Fitzcharles MA, Goldenberg DL, Katz
RS, Mease P, et al. The American College of Rheumatology preliminary diagnostic criteria for fibromyalgia and measurement of symptom severity. Arthritis Care Res. 2010;62(5):600-10.

35. Treede RD, Meyer RA, Raja SN, Campbell JN. Peripheral and central mechanisms of cutaneous hyperalgesia. Prog. Neurobiol. 1992;38(4):397-421.

36. Vierck Jr CJ, Staud R, Price DD, Cannon RL, Mauderli AP, Martin AD. The effect of maximal exercise on temporal summation of second pain (windup) in patients with fibromyalgia syndrome. J Pain. 2001;2(6):334-44.

37. Sarlani E, Greenspan JD. Why look in the brain for answers to temporomandibular disorder pain? Cells Tissues Organs. 2005;180(1):69-75.

38. Sarlani E, Grace EG, Reynolds MA, Greenspan JD. Sex differences in temporal summation of pain and aftersensations following repetitive noxious mechanical stimulation. Pain. 2004;109(1-2):115-23.

39. Lai YC, Shaftel SS, Miller JN, Tallents RH, Chang Y, Pinkert CA, et al. Intraarticular induction of interleukin1beta expression in the adult mouse, with resultant temporomandibular joint pathologic changes, dysfunction, and pain. Arthritis Rheum. 2006; Apr; 54(4):1184-97.

40. Staud R, Spaeth M. Psychophysical and neurochemical abnormalities of pain processing in fibromyalgia. CNS Spectr. 2008;13:12-7.

41. Aggarwal VR, McBeth J, Zakrzewska JM, Lunt M, Macfarlane GJ. The epidemiology of chronic syndromes that are frequently unexplained: Do they have common associated factors? Int J Epidemiol. 2006;35(2):468-76.

42. Diatchenko L, Nackley AG, Slade GD, Fillingim RB, Maixner W. Idiopathic pain disorders: Pathways of vulnerability. Pain. 2006;123(3):226-30.

43. Holm LW, Carroll LJ, Cassidy JD, Skillgate E, Ahlbom A. Widespread pain following whiplashassociated disorders: Incidence, course, and risk factors. J Rheumatol. 2007; 34(1):193-200.

44. Latremoliere A, Woolf CJ. Central sensitization: a generator of pain hypersensitivity by central neural plasticity. J Pain. 2009;10(9):895-926.

45. Staud R. Biology and therapy of fibromyalgia: pain in fibromyalgia syndrome. Arthritis Res Ther. 2006;8(3):1-7.

46. Crofford LJ, Young EA, Engleberg NC, Korszun A, Brucksch $\mathrm{CB}$, McClure LA, et al. Basal circadian and pulsatile $\mathrm{ACTH}$ and cortisol secretion in patients with fibromyalgia and/or chronic fatigue syndrome. Brain Behav Immun. 2004:18(4):314-25.

47. Crofford LJ. The hypothalamic-pituitary-adrenal axis in fibromyalgia: where are we in 2001? J Musculoskelet Pain. 2002:10:215-20.

48. Russell IJ, Orr MD, Littman B, Vipraio GA, Alboukrek D, Michalek JE, et al. Elevated cerebrospinal fluid levels of substance $\mathrm{P}$ in patients with the fibromyalgia syndrome. Arthritis Rheum. 1994;37(11):1593-601.

49. Bradley LA, Sotolongo A, Alberts KR, Alarcon GS, Mountz JM, Liu, HG, et al. Abnormal regional cerebral blood flow in the caudate nucleus among fibromyalgia patients and non-patients is associated with insidious symptom onset. $\mathrm{J}$ Musculoskelet Pain. 1999;7:285-92.

50. Larson AA, Giovengo SL, Russell IJ, Michalek JE. Changes in the concentrations of amino acids in the cerebrospinal fluid that correlate with pain in patients with fibromyalgia: implications for nitric oxide pathways. Pain. 2000;87(2):201-11. 
51. Giovengo SL, Russell IJ, Larson AA. Increased concentrations of nerve growth factor in cerebrospinal fluid of patients with fibromyalgia. J Rheumatol. 1999;26(7):1564-9.

52. Heinricher MM, Tavares I, Leith JL, Lumb BM. Descending control of nociception: specificity, recruitment and plasticity. Brain Res Rev. 2009;60(1):214-25.

53. Mayer DJ, Wolfle TL, Akil H, Carder B, Liebeskind JC. Analgesia from electrical stimulation in the brainstem of the rat. Science 1971;174(16):1351-4.

54. Porreca F, Ossipov MH, Gebhart GF. Chronic pain and medullary descending facilitation. Trends in Neurosciences. 2002;25(6):319-25

55. Eriksson P, Lindman R, Satal P, Bengtsson A. Symptoms and signs of mandibular dysfunction in primary fibromyalgia syndrome (PSF) patients. Swed Dent J. 1988; 12(4):141-9.

56. Hedenberg-Magnusson B, Ernberg M, Kopp S. Symptoms and signs of temporomandibular disorders in patients with fibromyalgia and local myalgia of the temporomandibular system. A comparative study. Acta Odontol Scand 1997;55(6):344-9.

57. Fricton JR. The relationship of temporomandibular disorders and fibromyalgia: implications for diagnosis and treatment. Curr Pain Headache Re. 2004;8(5):355-63.

58. Manfredini D, Tognini F, Montagnani G, Bazzichi L, Bombardieri S, Bosco M. Comparison of masticatory dysfunction in temporomandibular disorders and fibromyalgia. Minerva Stomatol. 2004;53(11-12):641-50.

59. Plesh O, Wolfe F, Lane N. The relationship between fibromyalgia and temporomandibular disorders: prevalence and symptom severity. J Rheumatol. 1996; 23(11):1948-52.

60. Leblebici B, Pektao ZO, Ortancil O, Hürcan EC, Bagis S, Akman MN. Coexistence of Fibromyalgia, temporomandibular disorder, and masticatory myofascial pain syndromes. Rheumatol Int.2007;27:541-4.

61. Fraga BP, Santos EB, Farias Neto JP, Macieira JC, Quintans LJ Jr, Onofre AS, et al. Signs and symptoms of temporomandibular dysfunction in fibromyalgic patients. J Craniofac Surg. 2012 Mar;23(2):615-8.

62. Rizzatti-Barbosa CM, Tallents RH, Dhadwal S, Malik S. May the loss of anterior teeth promotes pain in temporomandibular joint? Braz J Oral Scis. 2010;9:160-1.

63. Farias-Neto A, Martins APVB, Fiqueroba SR, Almeida SM, Groppo FC, Rizzatti-Barbosa CM. Altered mandibular growth under functional posterior displacement in rats. Angle Orthod. 2012;82(1):3-7.
64. Uhac I, Kovac Z, Valentic-Peruzovic M, Juretic M, Moro LJ. The influence of war stress on the prevalence of signs and symptoms of temporomandibular disorders. J Oral Rehabil. 2003;30(2): 211-7.

65. Vargas-Alarcon G, Alvarez-Leon E, Fragoso JM, Vargas A, Martinez A, Vallejo M, et al. A SCN9A gene-encoded dorsal root ganglia sodium channel polymorphism associated with severe fibromyalgia. BMC Musculoskelet Disord. 2012;13(23):1-5.

66. Mergener M, Becker RM, dos Santos AF, dos Santos GA, de Andrade FM. Influence of the interaction between environmental quality and T102C SNP in the HTR2A gene on fibromyalgia susceptibility. Rev Bras Reumatol. 2011;51(6):594-602.

67. Aneiros-Guerrero A, Lendinez AM, Palomares AR, Perez-Nevot B, Aguado L, Mayor-Olea A, et al. Genetic polymorphisms in folate pathway enzymes, DRD4 and GSTM1 are related to temporomandibular disorder. BMC Med Genet. 2011;12(75):1-9.

68. Diatchenko L, Robinson JE, Maixner W. Elucidation of mu-Opioid gene structure: how genetics can help predict responses to opioids. Eur J Pain Suppl. 2011;5(2):433-38.

69. Costigan M, Belfer I, Griffin RS, Dai F, Barrett LB, Coppola $\mathrm{G}$, et al. Multiple chronic pain states are associated with a common amino acid-changing allele in KCNS1. Brain. 2010;133(9):2519-27.

70. Tchivileva IE, Lim PF, Smith SB, Slade GD, Diatchenko L, McLean SA, et al. Effect of catechol-O-methyltransferase polymorphism on response to propranolol therapy in chronic musculoskeletal pain: a randomized, double-blind, placebocontrolled, crossover pilot study. Pharmacogenet Genomics. 2010;20(4):239-48

Received: 17/07/2012 Accepted: 18/09/2012

Corresponding author Luana Maria Martins de Aquino Department of Prosthesis and Periodontology UNICAMP - Piracicaba Dental School Av. Limeira, 901 - Zip Code: 13414-903. Piracicaba - SP - Brazil Tel./fax: +55 19 2106-5373 luanaquino@hotmail.com 